\title{
Original
}

\section{Observation of Caries Incidence Among a Tea-Drinking Population}

\author{
茶を飲用（飲茶）する人々の践蝕有病率の観察 \\ Cao JIN*, Chen YUE-ER*, Wu KAI-GUO* \\ Song XUE-NUI** and Nie ZHI-QING**

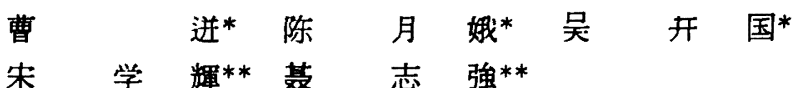

Received October 20, 1986 ; accepted February 19, 1987

\begin{abstract}
摡要：湘陰県県民の飲茶の仕方，食物成分の変化の調查を行い，3つの町の町民が常に湽んでいる茶のフ ッ素䈨度を測定し，さらに子供達が憡々な環境から掫取するフッ化物の量を計算して，以下のことを認めた。 地元の人々の 1 人当り毎月の砂䊀消费量は，1978年の $0.26 \mathrm{~kg}$ から 1986年の1.22kg に增加した。1978年の子 供の触有病事 $23 \%$ か，1986年には 19.76\%（p<0.01）に低下したことの主な原因は拎茶をするためであっ た。この地方の茶は，熱带や亚熱帯の発展途上国の低フッ素地区の子供達の腩予防に理想的なものである。 本研究では，このような国，あるいは地域の碑螌防を進めるために，適切な“湘陰モテル”を提案してい るのである。
\end{abstract}

\section{Koy words : Tea drinking, Caries Prevalence, Caries prevention}

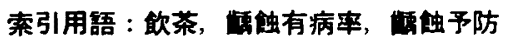

\section{Introduction}

The caries preventive effect of tea has been testified by experimental and epidemiological studies ${ }^{1,2)}$. However, reports of the relationship between tea drinking and the dynamics of caries epidemics in populations that have a traditional custom of tea drinking were few. The Chinese have a history of tea drinking of over 4000 years $^{3)}$. Xiang Yin county in Hunan province in China is a traditional tea production area. The sole water intake of the local people is through drinking tea. As the economy develops, the sales volume of cane sugar has increased several times in recent years in this county. But the caries prevalence in the children has decreased significantly. In order to explore the caries preventive effect of tea drinking, we have carried out eight years' observation of the productive characteristics of tea, the inhabitants' ways of tea drinking, the changes in contents of the food, and the fluoride contents of the tea and the various environmental factors in the county. The findings are reported as follows.

* Department of Stomatology, Xiang Yin County Hospital of Traditional Chinese Medicine, Hunan province, China

** Xiang Yin Hygiene and Anti-epidemic Station, Hunan province, China

* 中国湖南省湘阴县中医院口腔科

** 中国湖南省湘阴县卫生防度站 


\section{Materials and Methodes}

1) Social investigations: We have carried out an on-the-spot investigation of the production of tea in Xiang Yin county, collected samples of the local tea, and surveyed the inhabitants' ways of tea drinking and the contents of their food in 1978 and in 1986 at 101 households at 7 residental quarters in the town. Among them, there was a migrant household which was omitted. The sales volume of cane sugar in the town in 1978 and in 1986 was estimated. In 1978 and in 1986 we carried out an investigation of the habits of tea drinking, sweet food eating and tooth brushing of school children (7-17 years old) at the same 3 schools in the town.

2) Oral examination: Caries lesions were examined among school children with the ages of 7 to 17 at three schools in the town in 1978 and in 1986 . In 1978, we adopted the standards recommended by the Chinese Health Ministry about the national systematic caries survey to carry out the caries examination. Caries lesions were classified into five degrees. The losses of permanent teeth because of caries were counted as caries loss. Caries, losses, and repair of teeth were all counted as dental caries. Doubtful caries did not count. In 1986, we adopted the methods and tables recommended by the World Health Organization to examine caries. Caries, losses, and repair of teeth were still counted as dental caries. We used flat dental mirrors and sickle-form exploring needles to examine caries under natural light. In addition, we adopted Dean's classification method of five grades and examined dental fluorosis among 2536 pupils with ages of 7 to 17 under natural light in 1986. Both examinations in 1978 and in 1986 were conducted by the authors.

3) Measurement of fluoride: We used a fluoride ion electrode to measure fluoride of the dry tea leaves and of the tea infusions of green teas made by machine or by hand and of the forth-grade flower tea taken from the 100 households investigated. The same method was also used to measure fluoride of the water taken from a deep well which is the sole source of water in the town. Fluoride of the air of living rooms at the 7 residential quarters, rice, wheat flour, pork, eggs, salt, and some vegetables sold in the town was also measured.

4) We collected the local climatic phenomena data.

\section{Results}

1) According to the Xiang Yin County Annals written in 1497, tea leaves were a traditional product of the county at that time. The soil in the tea fields is red clay of the Quaternary Period. Its pH values are 4.5 to 6.5. The tea leaves are picked in May, July, and September every year. We observed that fresh tea leaves consisted of one sprout and three leaves, or stems and leaves from the picked fields. The high-grade and middle-grade tea leaves produced in tea factories were all made of these crude sprouts. Apart from their own needs, the farmers sale the surplus of elementary tea leave products to the nearby tea factories or to the townspeople. This kind of green tea is welcomed by the townspeople very much because of its tender appearance and its cheap price.

Xiang Yin town has a history of over 2000 years. The population in 1985 was 49930 . Owing to the history and the communications, the townspeople's habits of life have kept thick and heavy local colour all the time under influence of traditional culture. Although the modern ways of living have influenced the townspeople's life in recent years to a certain degree, tea drinking is still the sole route of water intake, and rice and vegetables are still the principal food. The townspeople usually buy a year's supply of tea leaves when fresh teas are in season, and then the put them into a dampproof earthenware or chinaware urn to be used the year. The townspeople think that old tea has an effect of clearing away heat and toxic materials. 
The tea has an orange colour and a good taste. The local people have the habit of taking a cup of tea after meals or during work outdoors. They drink hot tea with ginger and salt in spring, autumn and winter. In summer, they put the tea leaves or a mixture of salt, ginger and tea leaves into a large earthenware or chinawarepot and then put boiling water into it for a day's drink.

A special kind of soup with ginger, salt and tea leaves has been very popular all the time in the locality. The method for making it is as follows. First, raw ginger is ground into pieces in a special earthenwarecrock. Then the ground ginger pieces, salt and tea leaves are put proportionally in another earthenwarecrock. Finally, they are mixed with boiling water. The local people think that this kind of drink is necessary to remove fatigue and clear away heat and toxic materials. Guests and hosts interchange their feelings when they drink this kind of tea at joyous, congratulatory, wedding and funeral ceremonies.

The perennial samples at 100 households were green tea made by machine, green tea made by hand and fourth-grade flower tea. The prices of these teas were 4.80 yuan, 5.20 yuan, and 5.00 yuan per kilogram, respectively.

The local people think tea drinking might make infants and young children easy to be attacked by intestinal parasites and might impede sound sleep. Therefore, the local children ( 0 to 4 years old) drink principally sugar water or boiled water.

Changes in the contents of food of the 100 households are shown in Table 1.

Table 1 Changes in content of food

(the average monthly consumption per person)

\begin{tabular}{|c|c|c|c|c|c|c|c|c|}
\hline Years & Item & $\begin{array}{l}\text { Cane } \\
\text { sugar }\end{array}$ & $\begin{array}{c}\text { Tea } \\
\text { leaves }\end{array}$ & Rice & $\begin{array}{l}\text { Wheat } \\
\text { flour }\end{array}$ & Vegetables & Pork & Eggs \\
\hline 1978 & & 0.26 & 0.23 & 17.21 & 2.51 & 8.12 & 0.51 & 0.65 \\
\hline 1986 & & 1.22 & 0.25 & 15.36 & 3.47 & 7.53 & 3.35 & 3.52 \\
\hline
\end{tabular}

The figures in Table 1 are average values which equal the total amount of each kind of food in a month divided by the total number of members of the 100 families.

The sales volume of cane sugar, including candies, increased from 167.05 tonnes in 1978 to 706.7 tonnes in 1986 according to data from the two main sale systems of sugar in the county. On the whole, the increment of sugar sale in eight years accorded with the increment rates of sugar comsumption in the 100 families.

The children's habits are listed in Table 2.

Table 2 Children's habits in 1978 and 1986

\begin{tabular}{|c|c|c|c|c|c|c|c|c|}
\hline \multirow[b]{2}{*}{ Years } & & \multicolumn{2}{|c|}{ Ways of drinking water } & \multicolumn{2}{|c|}{ Sweets } & \multicolumn{3}{|c|}{ Tooth brushing } \\
\hline & & tea water & boiled water & yes & no & $\begin{array}{c}\text { vertical } \\
\text { brushing }\end{array}$ & $\begin{array}{l}\text { horizontal } \\
\text { brushing* }\end{array}$ & $\begin{array}{l}\text { no } \\
\text { habit of } \\
\text { brushing }\end{array}$ \\
\hline \multirow[t]{2}{*}{1978} & number & 2197 & 73 & 1327 & 943 & 76 & 1872 & 322 \\
\hline & $\%$ & 96.78 & 3.22 & 53.46 & 41.45 & 3.35 & 82.47 & 14.19 \\
\hline \multirow[t]{2}{*}{1986} & number & 2472 & 76 & 1696 & 840 & 140 & 2230 & 166 \\
\hline & $\%$ & 97.48 & 3 & 66.44 & 33.12 & 5.52 & 87.94 & 6.55 \\
\hline
\end{tabular}

* Brushning tooth surfaces on labial and buccal side horizontally 
Table 3 Caries prevalence rate in the children in Xiang Yin county town

\begin{tabular}{lcccccc}
\hline Years & $\begin{array}{c}\text { No. of } \\
\text { children }\end{array}$ & $\begin{array}{c}\text { No. of } \\
\text { cases with } \\
\text { dental } \\
\text { caries }\end{array}$ & $\begin{array}{c}\text { Caries } \\
\text { prevalence } \\
\text { rates }\end{array}$ & $\begin{array}{c}\text { No. of } \\
\text { dental } \\
\text { caries }\end{array}$ & $\begin{array}{c}\text { Means of } \\
\text { caries }\end{array}$ & $\begin{array}{c}\text { Means of } \\
\text { caries in } \\
\text { cases }\end{array}$ \\
\hline 1978 & 2270 & 521 & 23 & 1001 & 0.44 & 1.92 \\
1986 & 2536 & 501 & 19.76 & 1101 & 0.43 & 2.19 \\
\hline $\mathrm{u}=2.714$ & $\mathrm{p}<0.01$ & $\chi^{2}=7.307$ & $\mathrm{p}<0.01$ & & &
\end{tabular}

Taable 4 Age-specific caries prevalence rate in the children in Xiang Yin county town

\begin{tabular}{|c|c|c|c|c|c|}
\hline Ages & Years & $\begin{array}{l}\text { No. of } \\
\text { children }\end{array}$ & $\begin{array}{l}\text { Caries } \\
\text { prevalence } \\
\text { rates of } \\
\text { milk teeth }\end{array}$ & $\begin{array}{c}\text { Caries } \\
\text { prevalence } \\
\text { rates of } \\
\text { permanent } \\
\text { teeth } \\
\end{array}$ & $\begin{array}{l}\text { Caries } \\
\text { prevalence } \\
\text { rates of } \\
\text { mixed teeth }\end{array}$ \\
\hline \multirow[t]{2}{*}{7} & 1978 & 231 & $30.57^{* *}$ & $11.72^{* *}$ & $40.78 \uparrow$ \\
\hline & 1986 & 183 & 45.89 & 2.73 & 45.90 \\
\hline \multirow[t]{2}{*}{8} & 1978 & 217 & $31.58^{*}$ & $12.30^{* *}$ & $34.78 \dagger$ \\
\hline & 1986 & 219 & 40.78 & 5.58 & 42.00 \\
\hline \multirow[t]{2}{*}{9} & 1978 & 174 & $25.89 \dagger$ & $12.30^{*}$ & $33.81 \dagger$ \\
\hline & 1986 & 209 & 30.62 & 6.22 & 34.94 \\
\hline \multirow[t]{2}{*}{10} & 1978 & 221 & $15.40 \dagger$ & $12.46^{*}$ & $26.69^{* *}$ \\
\hline & 1986 & 242 & 14.88 & 6.20 & 15.28 \\
\hline \multirow[t]{2}{*}{11} & 1978 & 198 & $13.17^{*}$ & $11.32+$ & $20.36^{* *}$ \\
\hline & 1986 & 218 & 5.99 & 5.99 & 11.06 \\
\hline \multirow[t]{2}{*}{12} & 1978 & 191 & $9.12^{*}$ & $13.01 \dagger$ & $21.42^{*}$ \\
\hline & 1986 & 274 & 3.69 & 10.22 & 14.23 \\
\hline \multirow[t]{2}{*}{13} & 1978 & 235 & $10.23^{* *}$ & $12.34 \dagger$ & $16.75^{* *}$ \\
\hline & 1986 & 272 & 0.74 & 7.72 & 8.09 \\
\hline \multirow[t]{2}{*}{14} & 1978 & 207 & $0.55 \dagger$ & $14.93 \dagger$ & $14.93 \dagger$ \\
\hline & 1986 & 189 & 0.53 & 11.11 & 14.64 \\
\hline \multirow[t]{2}{*}{15} & 1978 & 213 & 0 & $16.74 \dagger$ & 0 \\
\hline & 1986 & 260 & 0 & 12.30 & 0 \\
\hline \multirow[t]{2}{*}{16} & 1978 & 191 & 0 & $16.51 \dagger$ & 0 \\
\hline & 1986 & 258 & 0 & 11.90 & 0 \\
\hline \multirow[t]{2}{*}{17} & 1978 & 192 & 0 & $20.83 \dagger$ & 0 \\
\hline & 1986 & 162 & 0 & 12.96 & 0 \\
\hline
\end{tabular}

** The difference was very significant.

* The difference was significant.

$\dagger$ The difference was not significant.

Table 5 Prevalence rate of dental fluorosis in the children in Xiang Yin county town

\begin{tabular}{|c|c|c|c|c|c|c|c|c|c|}
\hline \multirow{2}{*}{$\begin{array}{l}\text { No. of } \\
\text { children }\end{array}$} & \multirow{2}{*}{$\begin{array}{l}\text { No. of } \\
\text { case }\end{array}$} & \multirow{2}{*}{$\begin{array}{l}\text { Prevalence } \\
\text { rate of } \\
\text { dental } \\
\text { fluorosis }\end{array}$} & \multirow{2}{*}{$\begin{array}{l}\text { Index of } \\
\text { dental } \\
\text { fluorosis }\end{array}$} & \multicolumn{6}{|c|}{ Ratio of different degrees of dental fluorosis (\%) } \\
\hline & & & & Normal & Doubtful & $\begin{array}{c}\text { Very } \\
\text { Slight }\end{array}$ & Slight & Middle & Severe \\
\hline 2536 & 48 & 1.89 & 0.03 & 97.32 & 0.63 & 0.59 & 0.51 & 0.12 & 0.04 \\
\hline
\end{tabular}


2) Oral examination

As explained in materials and methods, we examined the school children (7-17 years old) at the same 3 schools in the town in April, 1978 and 1986. In 1978 we did not carry out the investigation of dental fluorosis. The results are as follows:

We found that the middle-degree and severe-degree cases with dental fluorosis were all pupils who had immigrated into the locality from other areas after seven years of age.

3) Results of fluoride measurement:

Table 6 Fluoride in the three kinds of tea leaves (ppm)

\begin{tabular}{llcccccc}
\hline \multirow{2}{*}{ Kinds } & & $\begin{array}{c}\text { No. of } \\
\text { samples }\end{array}$ & Range & Average & $\overline{\mathrm{X}} \pm \mathrm{SD}$ & $\overline{\mathrm{X}} \pm \mathrm{SE}$ & $\begin{array}{c}\text { 95\% confidence } \\
\text { limits }\end{array}$ \\
\hline Green tea & Dry sample & 4 & $179.1-199.2$ & 188.95 & 11.78 & 5.89 & $188.95 \pm 18.74$ \\
made with machines & Infusion & 4 & $0.33-0.51$ & 0.43 & 0.0129 & 0.00645 & $0.43 \pm 0.0205$ \\
Green tea & Dry sample & 4 & $434.5-456.3$ & 442.88 & 11.49 & 5.74 & $442.88 \pm 18.27$ \\
made by farmers & Infusion & 4 & $0.52-0.69$ & 0.59 & 0.075 & 0.037 & $0.59 \pm 0.12$ \\
The fourth grade & Dry sample & 4 & $639.3-660.1$ & 646.12 & 10.31 & 5.16 & $646.12 \pm 16.42$ \\
flower tea & Infusion & 4 & $0.68-0.83$ & 0.74 & 0.069 & 0.035 & $0.74 \pm 0.11$ \\
\hline
\end{tabular}

Table 7 Fluoride in the water, air and foods (ppm)

\begin{tabular}{llcccccc}
\hline \multicolumn{1}{c}{ Kinds } & Units & $\begin{array}{c}\text { No. of } \\
\text { samples }\end{array}$ & Range & Average & $\bar{X} \pm \mathrm{SD}$ & $\overline{\mathrm{X}} \pm \mathrm{SE}$ & $\begin{array}{c}\text { 95\% confidence } \\
\text { limits }\end{array}$ \\
\hline Water & $\mathrm{mg} / \mathrm{l}$ & 4 & $0.042-0.061$ & 0.05 & 0.00796 & 0.00398 & $0.05 \pm 0.013$ \\
Air & $\mathrm{mg} / \mathrm{m}^{3}$ & 7 & $0.0007-0.0012$ & 0.0008 & 0.000281 & 0.000106 & $0.0008 \pm 0.0002$ \\
Rice & $\mathrm{mg} / \mathrm{kg}$ & 6 & $0.067-0.086$ & 0.078 & 0.00824 & 0.00336 & $0.078 \pm 0.0086$ \\
Wheat & $\mathrm{mg} / \mathrm{kg}$ & 6 & $0.109-0.135$ & 0.124 & 0.00894 & 0.00365 & $0.124 \pm 0.0094$ \\
flour & $\mathrm{mg} / \mathrm{kg}$ & 6 & $0.051-0.113$ & 0.075 & 0.0225 & 0.00918 & $0.075 \pm 0.024$ \\
Vegetables & $\mathrm{mg} / \mathrm{kg}$ & 6 & $0.069-0.095$ & 0.082 & 0.0311 & 0.00991 & $0.082 \pm 0.031$ \\
Pork & $\mathrm{mg} / \mathrm{kg}$ & 6 & $0.066-0.073$ & 0.069 & 0.0212 & 0.00883 & $0.069 \pm 0.021$ \\
Eggs & $\mathrm{mg} / \mathrm{kg}$ & 6 & $0.45-0.61$ & 0.53 & 0.071 & 0.00989 & $0.53 \pm 0.12$ \\
Salt & & & & & & &
\end{tabular}

When calculating the total daily amount of fluoride taken by children based on Table 6,7 , we took the mean of fluoride taken from tea drinking, and supposed that the daily intake of tea, air, rice, wheat flour, pork, eggs, salt and vegetables per person was $1000 \mathrm{ml}, 10 \mathrm{~m}^{3}, 400 \mathrm{~g}, 100 \mathrm{~g}, 110 \mathrm{~g}, 120 \mathrm{~g}, 4.12 \mathrm{~g}$, and $400 \mathrm{~g}$, respectively.

Table 8 Total intake of fluoride $(\mathrm{mg})$ and percentages from different environment factors

\begin{tabular}{ccccccccccc}
\hline Kinds & Air & Water & $\begin{array}{c}\text { Tea } \\
\text { leaves }\end{array}$ & Rice & $\begin{array}{c}\text { Wheat } \\
\text { flour }\end{array}$ & $\begin{array}{c}\text { Vege- } \\
\text { tables }\end{array}$ & Pork & Eggs & Salt & Total \\
\hline $\begin{array}{c}\text { A mount of } \\
\text { intake } \\
\%\end{array}$ & 0.008 & 0.05 & 0.59 & 0.031 & 0.012 & 0.03 & 0.009 & 0.007 & 0.002 & 0.739 \\
\hline
\end{tabular}

4) The local climatic phenomena data

$\mathrm{Xiang} \mathrm{Y}$ in county is located in a monsoon climate area which is transitional from the middle subtropics 


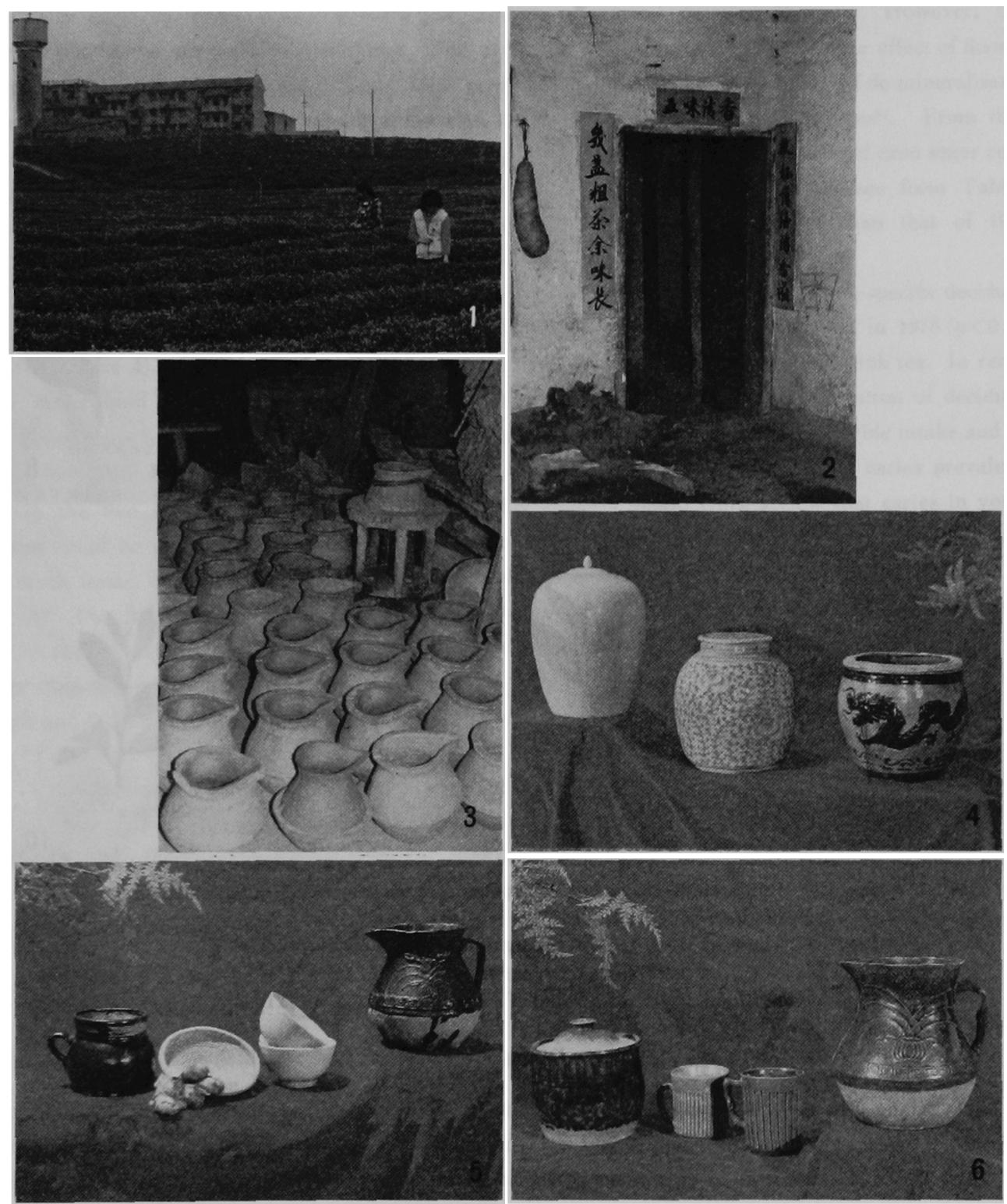

Fig. 1 A glimpse of the food market in Xian Yin.

Fig. 2 Spring festival coupletes on tea in villages.

Fig. 3 A corner of a pottery workshop making utensils for tea.

Fig. 4 Some pottery utensils for keeping tea in the peasants' families.

Fig. 5 Utensils for tea in summer.

Fig. 6 Utensils for making tea with ginger and salt.

to the north. The yearly average temperature is $17^{\circ} \mathrm{C}$. The lowest monthly average temperature is $4.5^{\circ} \mathrm{C}$, and the highest is $29.2^{\circ} \mathrm{C}$. The rainfall averages $1382.8 \mathrm{~mm}$ a year. The yearly relative degree of humidity averages $80 \%$. 

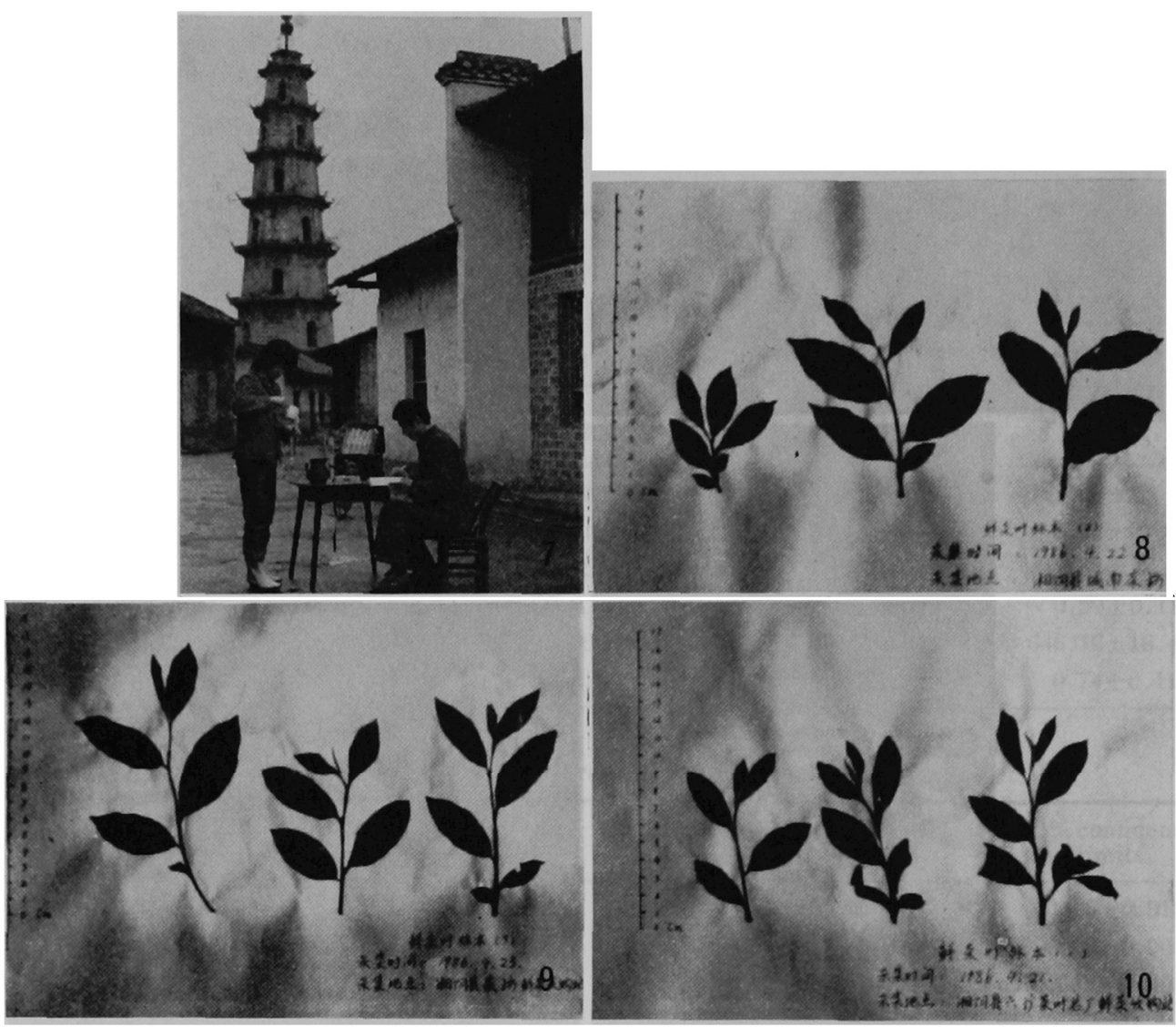

Fig. 7 Research workers collecting samples of tea with ginger and salt in the residential area.

Fig. 8 Mark of fresh tea in Chang Na commune, Xiang Yin.

Fig. 9 Mark of fresh tea in tea farm, Xian Yin.

Fig. 10 Mark of fresh tea in Liu Tang commune, Xian Yin.

\section{Discussion}

1) Xiang Yin town is a typical low fluoride area. The fluoride concentraion in its water source is $0.05 \mathrm{mg}$ per liter. The caries prevalence rates in eight years, however, were lower than the Chinese average rate $(33.3 \%)^{4}$. The local children's intake of fluoride from environmental factors without tea drinking was $0.149 \mathrm{mg}$. This amount of fluoride per day, is not enough to prevent caries. Tea drinking, however, could offer the children $0.59 \mathrm{mg}$ of fluoride, which reached $79.84 \%$ of the daily total intake of fluoride (Table 8). It would be seen from this that tea drinking is the main route of fluoride intake.

As the economy develops, the inhabitants' sales volume of cane sugar increases rapidly (Table 1). The good habit of brushing one's teeth has not been established among the children (Table 2). However, the caries prevalence rate in 1986 was $3.24 \%$ less than that of in $1978(p<0.01)$ (Table 3). The caries prevalence rate decreased because the children's age-specific rates decreased significantly at the ages of seven, eight, nine, and ten $(p<0.01, p<0.01, p<0.05, p<0.05)$ (Table 4). When the children became five years old or over, their principal food was rice and their sole route of water intake was tea drinking, similar to the adults. The children's permanent teeth germinated successively at six. When they ate 
fermentable sugar, the dental plaque became acid, and caused dental de-mineralization. However, they absorbed fluoride by means of tea drinking. The dental re-mineralization caused by the effect of fluoride ions replaced the de-mineralization. Thus, fresh permanent teeth kept the equilibrium of de-mineralization and re-mineralization. This has been demonstrated by many experiments and researches ${ }^{5}$. From these facts, we considered that it was possible that the degree of brushing teeth and intake of cane sugar could change the past fixed idea when fluoride was absorbed for a long time. We can still see from Table 1 that the local inhabitants' consumption of pork and eggs in 1986 was obviously more than that of 1978. This was very beneficial to the children in regard to caries prevention.

2) The other evidence of the caries preventive effect of fluoride was that the age-specific deciduous teeth caries prevalence rates of 7 and 8-year-olds in 1986 were significantly higher than in 1978 ( $p<0.01$, $\mathrm{p}<0.05$ ) (Table 4). The local infants and young children before 4 years of age do not drink tea. In recent years, refined and high sugar food has been consumed by the children. The mineralization of deciduous teeth takes place from the fifth month in the womb to three years of age. Lack of fluoride intake and the refined and high sugar content food might be the cause of rising of deciduous teeth caries prevalence rates in the two age groups mentioned above. This supports Masao Onisi's view that caries in young children could be prevented by taking fluoride ${ }^{8)}$. Considering that the infants and young children can not take much water, the tea leaves with more fluoride should be selected.

3) The local tea leaves were picked and processed roughly, so a large number of crude tea leaves were mixed in commercial tea. This is the main reason why the fluoride content of this kind of tea was higher than that of high-grade and middle-grade tea. Xiang Yin county is the subtropics. The temperature is high and the amount of tea drinking was large in summer. But epidemics of dental fluorosis did not occur (Table 5).

The appearance of this kind of tea was still tender after putting it into boiling water. The tea treated by fresh flowers was fragrant. These teas are ideal articles for caries prevention in developing countries from the point of view of safety, appearance, taste, and reasonable price. Further study is needed to see whether the soup with ginger, salt, and tea leaves drunk by the local people has better caries preventive effects than those of tea only.

\section{References}

1) Onisi, M. et al. : A field test on the caries preventive effect of tea drinking, J. Dent. Hlth., $31 ; 13-19,1981$.

2）曹迸: 莱叶防战的研究概况及其应用, 茶叶 通讯, $3 ; 44,1985$.
3）陆羽(唐)：茶经，乾隆本，1；1-2，1696.

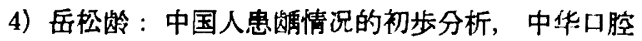
科杂志, $1 ; 1,1980$.

5）苗兰卿：踊病病因论的新概念，国外医学口腔分 册, $5 ; 262,1984$.

6）大西正男：茶叶防颃的研究，大西正男访华报告, 北京口腔医院骆少君整理, 10, 1980.

本論文は編集委員会の総意により，日中友好を考えて特別に揭载し，その費用は編集費から支払われたことを 付記する.

注）本論文の䐴要は堀井編集委員のご好意により中国語を日本語に翻訳したものである。 